\section{Intimate partner violence and unintended pregnancy: prevalence and associated factors}

\author{
Violência pelo parceiro íntimo e gravidez não \\ pretendida: prevalência e fatores associados
}

\author{
La violencia de género y los embarazos no \\ deseados: prevalencia y factores asociados
}

\author{
${ }_{1}$ Programa de Pós-graduação \\ em Saúde Coletiva, \\ Universidade Federal de \\ Pernambuco, Recife, Brasil. \\ Correspondence \\ T. V. B. Araújo \\ Programa de Pós-graduação \\ em Saúde Coletiva, \\ Universidade Federal de \\ Pernambuco. \\ Av. Prof. Moraes Rego s/n \\ Bloco E, 4o andar, Recife, PE \\ 50670-901, Brasil. \\ thalia@ufpe.br
}

\section{Abstract}

This study investigated the association between unintended pregnancy and intimate partner violence before pregnancy. A cross-sectional study was carried out with 1,054 women, aged 18 to 49, in Recife, Northeastern Brazil, from July 2005 to March 2006. Non-conditional logistic regression analysis was performed with a hierarchical strategy for entering variables into the model, according to the conceptual framework defined. Unintended pregnancy was reported by $60.3 \%$ (636) women. Intimate partner violence prior to the pregnancy was associated with unintended pregnancy $\left(O R_{a d j}=1.57 ; 95 \% C I: 1.17-2.11\right)$, even when adjusted for the women's sociodemographic characteristics, the partner's behaviour, and the relationship dynamic. When the association was adjusted for the use of contraception and the partner's refusal to use contraception, the association was no longer significant, suggesting that the effect of partner violence on unintended pregnancy may be mediated by these variables. The findings point to the need of screening for intimate partner violence in reproductive health services.

Violence Against Women; Spouse Abuse; Unplanned Pregnancy; Reproductive Health
Ana Carolina da C. Azevêdo ${ }^{1}$

Thália Velho Barreto de Araújo 1

Sandra Valongueiro ${ }^{1}$

Ana Bernarda Ludermir 1

\section{Resumo}

Este estudo investigou a associação entre gravidez não pretendida e violência por parceiro intimo antes da gravidez atual. Estudo transversal foi realizado com 1.054 mulheres, com idade entre 18 e 49, residentes no Recife, Nordeste do Brasil, entre julho de 2005 e março de 2006. Utilizou-se análise de regressão logística com estratégia hierarquizada para a inserção de variáveis no modelo, de acordo com o quadro conceitual definido. Gravidez não pretendida foi relatada por 60,3\% (636) das mulheres. Violência por parceiro íntimo antes da gravidez foi associada com gravidez não pretendida $\left(O R_{\text {ajustado }}=\right.$ 1,57; IC95\%: 1,17-2,11), mesmo quando ajustada para as características demográficas e socioeconômicas das mulheres, pelo comportamento do parceiro e dinâmica da relação. Quando a associação foi ajustada pelo uso de contracepção e recusa do parceiro ao uso de contracepção, houve perda da significância estatística. Isso sugere que o efeito da violência por parceiro íntimo sobre gravidez não pretendida pode ser mediado por tais variáveis. Os achados apontam a necessidade de rastreamento da violência por parceiro íntimo nos serviços de saúde reprodutiva.

Violência Contra a Mulher; Maus-Tratos Conjugais; Gravidez Não Planejada; Saúde Reprodutiva 


\section{Introduction}

Unintended pregnancy has been incorporated into the reproductive health research agenda due to its adverse outcomes for women and child's health 1 . This is a difficult area of reproductive health to study, especially because the terms "unwanted", "unplanned" and "unintended" have different meanings for the women and for researchers ${ }^{2,3}$. In some studies 4 , the intention to get pregnant is investigated retrospectively, when women are already pregnant, and is based on what they report about their reproductive intentions prior to becoming pregnant. In other studies 2,3 , this term has overlapped with "planned pregnancies", using different criteria to classify a pregnancy as intended or otherwise.

While the use of contraceptives in Brazil is widespread, there is also a high proportion of unintended pregnancies. The National Survey of Demographic and Health 2006 (PNDS 2006) estimated that, of all births occurred in Brazil between 2001 and 2006, 46\% were unplanned, 28\% of which being mistimed and $18 \%$ unwanted 5 .

Few studies have directly addressed the association between intimate partner violence and unintended pregnancy 6,7,8,9,10,11. In Latin America, studies carried out in Colombia 8 and Peru 10 revealed a higher risk of unintended pregnancy among women who had suffered physical or sexual violence by an intimate partner.

Violence by an intimate partner is highly prevalent in Brazil. The World Health Organization's (WHO) multi-country study on violence against women 12 revealed that, in the city of São Paulo, $41.8 \%$ of women reported having suffered psychological violence at least once in their lifetimes, $27.2 \%$ physical, and $10.1 \%$ sexual. In a rural area of Pernambuco, $48.9 \%$ of the violence reported was psychological, $33.7 \%$ physical, and $14.3 \%$ sexual. Violence by an intimate partner is also frequent during pregnancy 13. A cross-sectional study 14 carried out to estimate the prevalence of this kind of violence among a sample of 2,156 women, aged 15 to 49 years, users of the Family Health Program (FHP), the Brazilian primary health care program, between 2005 and 2006 , showed that $52.2 \%$ of women reported at least one form of intimate partner violence (physical, sexual, or psychological) in the course of their lives. When investigated in relation to the most recent or current partner in the previous year, this prevalence increased to $70.1 \%$ for any kind of violence.

The aim of this study was to investigate the prevalence of unintended pregnancy and its association with intimate partner violence prior to the current pregnancy among women whose pregnancy progressed to a birth. The study was also designed to estimate the prevalence of intimate partner violence in the relationship with the current or most recent partner, prior to the current pregnancy.

The theoretical framework included gender issues, which encourage men to behave violently towards their partners and undermine the social, sexual, and reproductive autonomy of women. This can reduce women's power to negotiate contraceptive use with their partners and lead to a lack of control over reproductive intentions 15,16,17,18.

\section{Methods}

\section{Study area and design}

A cross-sectional study was carried out using the baseline data of a cohort study designed to investigate intimate partner violence and adverse maternal and perinatal outcomes. It was conducted in Recife, the State capital of Pernambuco, northeastern Brazil, between July 2005 and March 2006. The area studied was Health District II (one of the city's six health districts), which has a population of 217,293 inhabitants, representing almost $15 \%$ of the total population of Recife. In the last Demographic Census Recife had a high proportion of low-income families 19.

All pregnant women aged 18 to 49 years, living in Health District II and registered at the FHP, were eligible for inclusion in the original study. Of 1,133 women identified, 1,121 (99\%) were interviewed. They were identified from prenatal care records of 42 primary care teams and from the records of community health workers in order to include those not receiving prenatal care at FHP units. In this analysis 1,054 women were included who had been in a sexual-affective relationship for at least six months, regardless of formal marriage or cohabitation, and also had complete data for all analyzed variables.

The FHP coverage is about $78 \%$ of the population of Recife 19. Given that the criteria for the registration of families on the FHP are the same in all areas of the city, these results can be generalized to all women attended by the FHP in Recife.

\section{Procedures}

Face-to-face interviews using a structured questionnaire with closed questions were conducted by university-educated female interviewers. Most interviews were conducted at a healthcare unit, but some women were interviewed at home by request. Women were contacted and interviewed 
in the third trimester of pregnancy, but 81 (7.9\%) had already given birth at the period of the interview due to a premature birth.

\section{Variables}

The dependent variable, unintended pregnancy, was drawn from a question that asked whether the woman, before knowing that she was pregnant: (a) "was trying to get pregnant"; (b) "wanted to get pregnant"; (c) "wanted to get pregnant later" (mistimed); (d) "did not want to get pregnant" or (e) "did not care either way". The answers classified as unintended pregnancy were the alternatives (c) and (d). The first two options were classified as intended pregnancy. For women who said that they "did not care either way" ( $\mathrm{n}=$ 41), a detailed analysis of the questionnaires was performed, using other issues to classify pregnancies as intended or unintended (reasons for not wanting to get pregnant, her reaction to the pregnancy, contraceptive use in the period prior to pregnancy, and reproductive intention). In the same way, pregnancy intention by the partner was also classified as intended or unintended.

The intimate partner was defined as the current or former partner with whom the woman was living or had lived, irrespective of whether the relationship was a formal union or a situation of cohabitation.

Intimate partner violence, the main independent variable, was classified as physical, psychological, and sexual, based on questions from the WHO Multi-country Study on Women's Health and Domestic Violence ${ }^{12}$, which was validated in Brazil 20. Physical violence was identified based on women's report of at least one of the following partner's behaviors: shoving, slapping, punching, kicking or beating, choking, or using a weapon such as a gun, a knife or others. Psychological violence was based on insult, humiliation, intimidation, or threat, and sexual violence was defined as being physically forced to practice sexual intercourse, practicing sexual intercourse due to fear or intimidation, or practicing sex in a manner the women considered degrading. These questions have been presented elsewhere 13,21 . In the multivariate analysis, intimate partner violence was classified using two categories: having suffered some kind of violence or not having suffered violence by the partner. To ascertain the prevalence of intimate partner violence, all cases of psychological, physical and sexual violence were taken into consideration, both separately and with overlaps, inflicted by the current or most recent partner and occurring any time during the relationship before pregnancy.
Years of schooling were divided into three categories: 0-4 years, 5-8 years and 9 years or more. The classification of women's employment status was adapted from the classification adopted by the Brazilian Institute of Geography and Statistics (IBGE) in the 1991 Census 22 and categorized as: (a) employed regardless of a formal contract, self-employed, employers; (b) housewife, retired, or unemployed, (c) students (those still attending school irrespective of having a job or otherwise). The latter were placed in a separate group, as they showed a greater probability of suffering intimate partner violence.

The use of alcohol by the partner was classified as abusive when the woman reported seeing him drunk "every day or nearly every day" or "once or twice per week" in the last 12 months. Use of drugs was classified as yes/no according to whether the woman stated that her partner used or did not use illicit drugs.

Marital status was categorized as: currently married, living with partner, dating with a sexual relationship; without a sexual-emotional partner at the time of the interview. The length of the relationship was initially categorized into four groups: less than 1 year, 1 to 4 years, 5 to 7 years, 8 or more years. In the multivariate analysis the variable was dichotomized.

Partner controlling behavior (yes/no) was present when women answered positively that he restricted her contact with friends, relatives or other men, was suspicions of infidelity, or attempted to prevent her from working or studying and her access to health services.

The use of contraceptives at conception was classified as: use/non-use of any method. Reproductive intention referred to the ratio between the number of previous live births and the number of births desired by women (higher than/ less than or equal to). Partner's refusal to use contraception (yes/no) was identified when the woman reported that her partner had at any time refused, objected to, or tried to prevent her from using some contraceptive method.

\section{Statistical analysis}

Variables were first analyzed in a bivariate manner to identify those to be included in the unconditional logistic regression. In a second step, because of the complex interrelationship between intimate partner violence and unintended pregnancy, a conceptual framework was used to describe the hierarchical relationship between risk factors (Figure 1). The framework comprised three levels, each containing several variables: a) Level 1: socio-demographic characteristics of the women (age, years of study, and employ- 


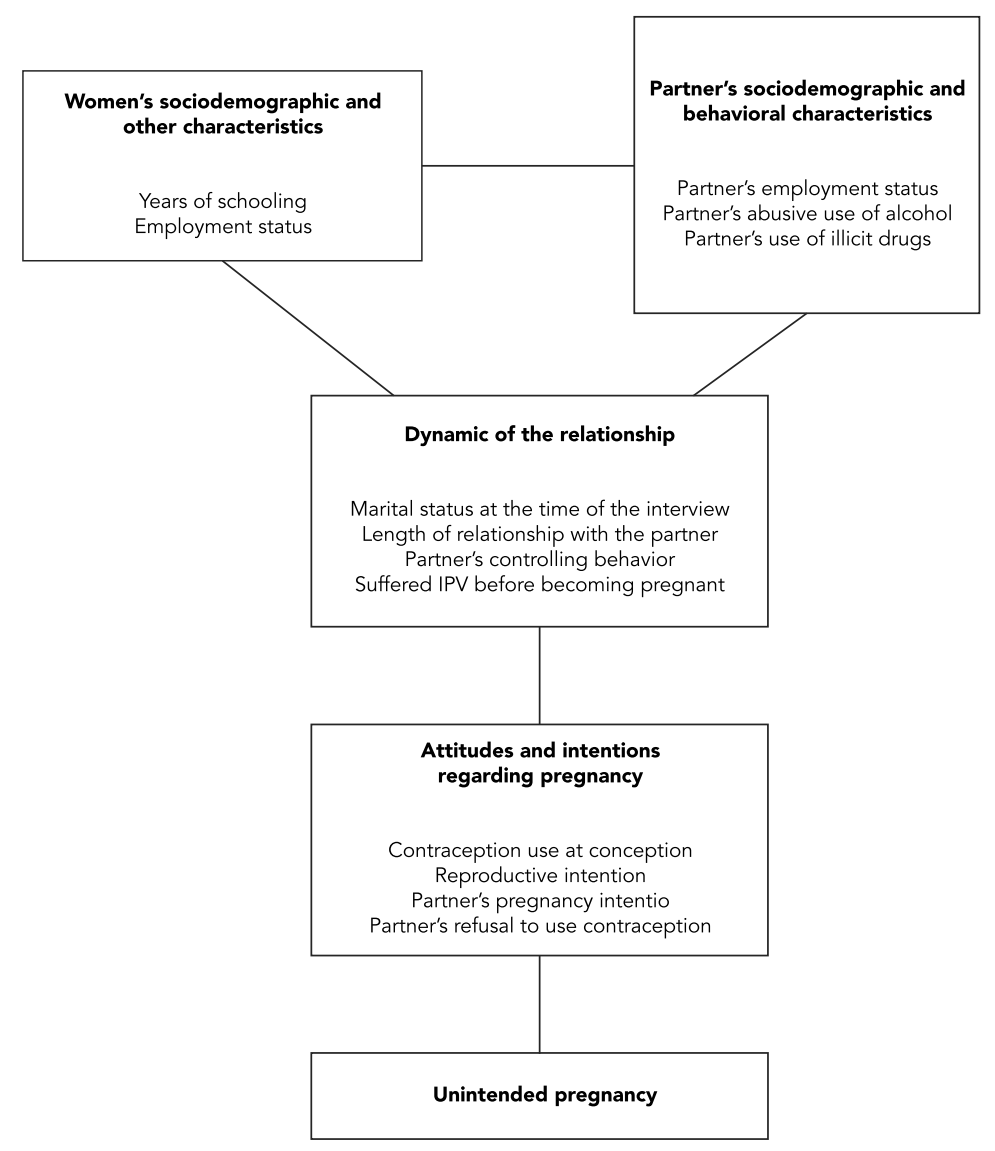

ment status) and characteristics of the partner (employment status, alcohol abuse, and illicit drug use);

b) Level 2: variables relating to the dynamic of the relationship (marital status, length of relationship, partner's controlling behavior, and having suffered intimate partner violence before the current pregnancy);

c) Level 3: attitudes and intentions regarding pregnancy (use of contraceptive methods at conception, reproductive intention, partner's pregnancy intention, and partner's refusal to use contraception). Regression analysis with stepwise forward selection of variables was performed, with a hierarchical strategy for entering variables into the model, according to the conceptual framework previously defined.

In each step, a significance of $p$-value $<0.20$ was required to enter into the logistic model.
Variables were retained in the model if they had $\mathrm{p}$-value $\leq 0.05$ for the likelihood ratio test, after adjustment for variables in the same level. The remaining variables were carried forward and included together with the variables in the next step of the framework. The variables that showed statistical significance at a certain level remained in the model in subsequent levels. They were considered factors associated with unintended pregnancy even if they lost statistical significance after inclusion in the set of hierarchically lower variables. According to this approach, some variables are assumed to mediate their effect through other independent variables as well as directly 23 . Interaction and collinearity between variables were investigated. Statistical analysis was performed using SPSS for Windows (SPSS Inc., Chicago, USA) version 15. 
Sociodemographic and other characteristics of participants, and association of these characteristics with unintended pregnancy.

\begin{tabular}{|c|c|c|c|c|}
\hline Factors & $\begin{array}{c}\text { Unintended } \\
\text { pregnancy \% (n) }\end{array}$ & Crude OR & $95 \% \mathrm{Cl}$ & p-value \\
\hline \multicolumn{5}{|l|}{ Age (years) } \\
\hline 19 or less & $62.2(89)$ & 1.22 & $0.78-1.93$ & $<0.3624$ \\
\hline 20 to 29 & $60.9(423)$ & 1.15 & $0.84-1.59$ & $<0.3653$ \\
\hline 30 or more & $57.4(124)$ & 1.00 & - & - \\
\hline \multicolumn{5}{|l|}{ Years of schooling } \\
\hline 4 or less & $64.8(160)$ & 1.66 & $1.18-2.34$ & 0.0023 \\
\hline 5 to 8 & $65.2(268)$ & 1.69 & $1.26-2.27$ & $<0.0002$ \\
\hline 9 or more & $52.5(208)$ & 1.00 & & - \\
\hline \multicolumn{5}{|l|}{ Employment status } \\
\hline Unemployed & $61.5(464)$ & 1.33 & $0.99-1.79$ & 0.051 \\
\hline Still attending school & $74.1(43)$ & 2.39 & $1.21-4.76$ & 0.006 \\
\hline Employed & $54.5(239)$ & 1.00 & - & - \\
\hline \multicolumn{5}{|l|}{ Partner's employment status } \\
\hline Unemployed & $69.5(153)$ & 1.66 & $1.21-2.28$ & 0.002 \\
\hline Employed & $57.9(483)$ & 1.00 & - & - \\
\hline \multicolumn{5}{|l|}{ Partner's abusive use of alcohol } \\
\hline Weekly & $65.5(112)$ & 1.44 & $1.00-2.09$ & 0.0420 \\
\hline Monthly & $64.6(186)$ & 1.39 & $1.03-1.87$ & 0.0275 \\
\hline Never & $56.8(338)$ & 1.00 & - & - \\
\hline \multicolumn{5}{|l|}{ Partner's use of illicit drugs } \\
\hline Yes & $79.5(62)$ & 2.71 & $1.54-4.77$ & $<0.0001$ \\
\hline No & $58.8(574)$ & 1.00 & - & - \\
\hline \multicolumn{5}{|l|}{ Marital status at the time of the interview } \\
\hline Without sexual-emotional partner & $81.8(90)$ & 3.75 & $2.21-6.42$ & $<0.0000$ \\
\hline Dating with a sexual relationship & $73.9(119)$ & 2.36 & $1.59-3.51$ & $<0.0000$ \\
\hline Currently married/living with partner & $54.5(427)$ & 1.00 & - & - \\
\hline \multicolumn{5}{|c|}{ Length of relationship with the partner (years) } \\
\hline 4 or less & $62.4(352)$ & - & - & - \\
\hline 5 to 7 & $53.0(125)$ & - & - & - \\
\hline 8 or more & $62.6(159)$ & 1.00 & - & - \\
\hline \multicolumn{5}{|l|}{ Partner's controlling behavior } \\
\hline Yes & $63.1(476)$ & 1.50 & $1.14-1.96$ & 0.004 \\
\hline No & $53.3(160)$ & 1.00 & - & - \\
\hline \multicolumn{5}{|l|}{ Suffered intimate partner violence before } \\
\hline \multicolumn{5}{|l|}{ becoming pregnant } \\
\hline Yes & $69.5(237)$ & 1.79 & $1.36-2.36$ & 0,000 \\
\hline No & 55.9 (399) & 1.00 & - & - \\
\hline \multicolumn{5}{|l|}{ Contraception use at conception } \\
\hline Yes & $89.2(321)$ & 9.90 & $6.88-14.26$ & 0.000 \\
\hline No & $45.4(315)$ & 1.00 & - & - \\
\hline \multicolumn{5}{|l|}{ Women's reproductive intention } \\
\hline Greater than intended & $85.3(238)$ & 6.46 & $4.36-9.60$ & $<0.0001$ \\
\hline Equal to intended & $57.5(176)$ & 1.51 & $1.12-2.04$ & 0.006 \\
\hline Less than intended & $47.3(222)$ & 1.00 & - & - \\
\hline \multicolumn{5}{|l|}{ Partner's pregnancy intention } \\
\hline Unintended & $81.9(363)$ & 5.62 & $4.20-7.51$ & $<0.0001$ \\
\hline Intended & $44.7(273)$ & 1.00 & - & - \\
\hline \multicolumn{5}{|l|}{ Partner's refusal to use contraception } \\
\hline Yes & $72.1(132)$ & 1.89 & $1.33-2.68$ & $<0.0001$ \\
\hline No & $57.9(504)$ & 1.00 & - & - \\
\hline
\end{tabular}

OR: odds ratio; $95 \% \mathrm{Cl}$ : $95 \%$ confidence interval. 


\section{Ethical considerations}

The study was approved by the Research Ethics Committee of the Center for Health Sciences at the Federal University of Pernambuco. At the beginning of the interview, each participant was given a brief account of the study, her consent was requested, and she was informed that the interview could be halted at any time. All interviewees received a guide indicating police, legal, social, psychological and medical services available in Recife for women who were victims of violence.

\section{Results}

Of the 1,054 women interviewed, 60.3\% (636) reported unintended pregnancy. Rates were higher among younger (under 30 years), less educated (8 years of study or less), and unemployed women, as well as those still attending school. Most of these women's partners were unemployed, abusive users of alcohol, and users of illicit drugs.

Most of the women who did not intend to get pregnant, were not living with their partner or were separated at the time of the interview, had up to 4 years or more than 8 years of relationship, and had suffered controlling behavior by the partner.

Moreover, the number of children of women who reported unintended pregnancy was greater or equal to what they intended, they had been using contraceptive methods at conception, and their partners did not intend pregnancy and had expressed refusal, disapproval, or tried to avoid the use of contraception (Table 1).

Intimate partner violence suffered prior to the current pregnancy was reported by $32.4 \%$ ( $n=$ 341) of women (Table 1). Most aggressor partners (85.1\%) were fathers of the child. Among those who reported intimate partner violence, $69.5 \%$ of pregnancies were unintended (crude OR = 1.79; 95\%CI: 1.36-2.36). In the subgroup who reported psychological violence alone, the probability of unintended pregnancy was 1.55 (95\%CI: 0.982.46); for those who reported physical and/or sexual violence, it was 1.75 (95\%CI: 1.24-2.48); and for those who reported all forms of violence, it was 3.15 (1.37-7.52), in comparison with those that had not suffered violence.

The hierarchical analysis is presented in Table 2. In the first level, still attending school, having less education, having a partner who was unemployed, and having a partner who used illicit drugs remained associated with unintended pregnancy, even after adjustment for the variables in this level (women's years of study, wom- en's employment status, partner's employment status, partner's abusive use of alcohol, and partner's use of illicit drugs).

At the second level, women's marital status, length of relationship with her partner, and having suffered intimate partner violence were the variables that remained associated with unintended pregnancy. After adjustment for the variables present in this level (marital status at interview, length of relationship with the partner, partner's controlling behavior) and those that remained from the previous step (women's years of study, women's employment status, partner's employment status, and partner's use of illicit drugs), intimate partner violence remained associated with unintended pregnancy $\left(\mathrm{OR}_{\mathrm{adj}}=1.57\right.$; 95\%CI: 1.17-2.11; $\mathrm{p}=0.001$ ).

At the third level, using contraceptive methods at conception, having already given birth to an equal or greater number of children than intended, having a partner who did not want the pregnancy or who had expressed displeasure, disapproval, or tried to avoid the use of contraception were associated with unintended pregnancy, after adjustment for the variables in this level and those retained from the previous step (women's years of study, women's employment status, partner's employment status, partner's use of illicit drugs, marital status at interview, length of relationship with the partner). In the presence of variables related to contraceptive behavior and the reproductive intention of the women and their partners, the association between IPV and unintended pregnancy was no longer significant $\left(\mathrm{OR}_{\mathrm{adj}}=1.01\right.$; 95\%CI: 0.71-1.44; $\left.\mathrm{p}=0.947\right)$.

No interaction was observed between intimate partner violence and the other independent variables, nor was there indication of collinearity between them in the adjusted models.

\section{Discussion}

As far as we are aware, this is the first population-based study to investigate the association between intimate partner violence and unintended pregnancy in Brazil and it is one of the few studies 6,11 specifically designed to examine this association.

The prevalence of unintended pregnancy found in this study was $60.3 \%$, which is higher than the estimates observed nationally in Brazil 5. However, a population-based study conducted in 200724 revealed $65 \%$ of pregnancies to be unplanned in a municipality of Rio Grande do Sul 24. In the international literature, the prevalence ranges from 18.5 to $65.3 \% 6,7,8$, $9,10,11,25,26,27,28,29,30,31$. Our findings may reflect 
Table 2

Hierarchical analysis of variables and unintended pregnancy.

\begin{tabular}{|c|c|c|c|c|c|}
\hline \multirow[t]{2}{*}{ Factors } & \multirow{2}{*}{$\begin{array}{c}\text { Crude OR } \\
(95 \% \mathrm{Cl})\end{array}$} & \multicolumn{4}{|c|}{ Adjusted OR (95\%Cl) } \\
\hline & & Level 1 (step 1) * & Level 1 (step 2) ** & Level $2 * \star \star$ & Level 3 \# \\
\hline \multicolumn{6}{|l|}{ Years of study } \\
\hline 4 or less & $1.66(1.18-2.34)$ & $1.71(1.21-2.42)$ & $1.48(1.04-2.11)$ & $1.33(0.93-1.91)$ & $1.05(0.67-1.64)$ \\
\hline 5 to 8 & $1.69(1.26-2.27)$ & $1.69(1.25-2.27)$ & $1.54(1.14-2.09)$ & $1.54(1.14-2.08)$ & $1.11(0.78-1.62)$ \\
\hline 9 or more & 1.00 & 1.00 & 1.00 & 1.00 & 1.00 \\
\hline \multicolumn{6}{|l|}{ Employment status } \\
\hline Unemployed & $1.33(0.99-1.79)$ & $1.08(0.80-1.47)$ & $1.07(0.79-1.46)$ & $1.10(0.81-1.51)$ & $1.01(0.69-1.49)$ \\
\hline Still attending school & $2.39(1.21-4.76)$ & $2.24(1.18-4.27)$ & $2.14(1.12-4.10)$ & $2.02(1.04-3.90)$ & $2.86(1.33-6.14)$ \\
\hline Employed & 1.00 & 1.00 & 1.00 & 1.00 & 1.00 \\
\hline \multicolumn{6}{|l|}{ Partner's employment status } \\
\hline Unemployed & $1.66(1.21-2.28)$ & & $1.47(1.06-2.04)$ & $1.37(0.98-1.92)$ & $1.04(0.70-1.55)$ \\
\hline Employed & 1.00 & & 1.00 & 1.00 & 1.00 \\
\hline \multicolumn{6}{|l|}{ Partner's abusive use of alcohol } \\
\hline Yes & $1.41(1.09-1.81)$ & & $1.23(0.94-1.59)$ & - & - \\
\hline No & 1.00 & & 1.00 & - & - \\
\hline \multicolumn{6}{|l|}{ Partner's use of illicit drugs } \\
\hline Yes & $2.71(1.54-4.77)$ & & $2.25(1.26-4.00)$ & $1.84(1.02-3.32)$ & $1.63(0.82-3.23)$ \\
\hline No & 1.00 & & 1.00 & 1.00 & 1.00 \\
\hline \multicolumn{6}{|l|}{ Marital status at the time of the interview } \\
\hline Without partner & $3.28(1.99-5.42)$ & & & $2.63(1.57-4.41)$ & $2.14(1.18-3.86)$ \\
\hline Still with the partner & 1.00 & & & 1.00 & 1.00 \\
\hline \multicolumn{6}{|c|}{ Length of relationship with the partner (years) } \\
\hline$\leq 4$ or $\geq 8$ & $1.48(1.10-1.98)$ & & & $1.47(1.09-1.99)$ & $1.67(1.15-2.44)$ \\
\hline 5 to 7 & 1.00 & & & 1.00 & 1.00 \\
\hline \multicolumn{6}{|l|}{ Suffered intimate partner violence before } \\
\hline \multicolumn{6}{|l|}{ becoming pregnant } \\
\hline Yes & $1.79(1.36-2.36)$ & & & $1.57(1.17-2.11)$ & $1.01(0.71-1.44)$ \\
\hline No & 1.0 & & & 1.00 & 1.00 \\
\hline \multicolumn{6}{|l|}{ Partner's controlling behavior } \\
\hline Yes & $1.50(1.14-1.96)$ & & & $1.14(0.85-1.52)$ & - \\
\hline No & 1.00 & & & 1.00 & - \\
\hline \multicolumn{6}{|l|}{ Contraception use at conception } \\
\hline Yes & $9.90(6.88-14.26)$ & & & & $8.79(5.90-13.11)$ \\
\hline No & 1.00 & & & & 1.00 \\
\hline \multicolumn{6}{|l|}{ Reproductive intention } \\
\hline Equal to or greater than intended & $5.50(3.84-7.88)$ & & & & $4.64(3.06-7.04)$ \\
\hline Less than intended & 1.00 & & & & 1.00 \\
\hline \multicolumn{6}{|l|}{ Partner's pregnancy intention } \\
\hline Unintended & $5,62(4.20-7.51)$ & & & & $4.32(3.09-6.04)$ \\
\hline Intended & 1.00 & & & & 1.00 \\
\hline \multicolumn{6}{|l|}{ Partner's refusal to use contraception } \\
\hline Yes & $1.87(1.33-2.68)$ & & & & $1.99(1.29-3.06)$ \\
\hline No & 1.00 & & & & 1.00 \\
\hline
\end{tabular}

OR: odds ratio; $95 \% \mathrm{Cl}$ : $95 \%$ confidence interval.

* For socioeconomic and demographic factors of the women;

* For variables selected at level 1, step 1 and for variables related to socioeconomic and behavioral characteristics of the partner;

*** For variables selected at level 1 (steps 1 and 2) and for variables related to the relationship dynamic;

\# For variables selected at levels 1 and 2 and for variables related to attitudes and intentions regarding pregnancy (level 3). 
the context of the population studied, since it consisted of women with low socioeconomic status and a considerable proportion of ineffective use of contraception. Several studies 30,32, including one carried out in Brazil 33, have shown that lower levels of education are associated with unintended pregnancy. Women in this condition may have less access to information and to contraceptive methods, as well as less autonomy in relation to reproductive decisions.

The comparability of our findings with other studies is difficult to establish, since the studies mentioned 2,3,8,10,25,26,27,28,29,30,31 differ in socio-cultural context and in the definition of unintended pregnancy, as well as the fact that the population studied included non-pregnant women, women who were pregnant in the last five years, who were in postpartum, or even women who had had an abortion as the outcome of pregnancy.

Investigating pregnancy intention involves certain conceptual difficulties ${ }^{3}$. The terms unintended, unplanned, or unwanted have different meanings for the women and are influenced by unconscious factors, life circumstances, past experiences, and social representations of motherhood and procreation 2,3 .

A prevalence of $32.4 \%$ was found for intimate partner violence. Although high, this may be underestimated because the approach to the issue of violence in the context of sexual-affective relationships has showed to be a difficult and sensitive subject to address in epidemiological research 34 . It is possible that women underreport intimate partner violence for shame or fear of exposing this type of experience or being stigmatized 6,34. Physical violence may have been underreported for fear of reprisals and further aggression by the partner. Sexual violence, in turn, may have been underreported, according to the representation of sex within marriages or unions in different cultures, such as unconditional sex for men 35 .

These findings indicate that having suffered intimate partner violence is associated with unintended pregnancy, even when adjusted for the socio-demographic characteristics of women, the socio-economic and behavioral characteristics of the partner, and the variables relating to the dynamic of the relationship. Our estimate is consistent with previous studies in Latin America that showed an association between intimate partner violence and the events studied 8,10 .

However, when all variables at the third level, which are closer to pregnancy intention, were included in the multivariate analysis, the association was attenuated. This suggests that the effect of intimate partner violence on unintended pregnancy may be mediated by the ineffective use of contraception, as well as the attitudes of disapproval, refusal, or partner's attempts to avoid the use of contraception. Women who reported intimate partner violence most frequently mentioned the use of contraception in the period prior to pregnancy and a higher proportion of unintended pregnancy when compared to those who did not report violence. Inconsistent use of contraceptive may express the great difficulty involved in negotiating contraception for women in violent relationships. Fanslow et al. 36 have pointed out that a partner's refusal to use contraception may be an indicator of violence in the context of relationships between couples, which is reiterated by Brazilian studies 17,36,37.

Some studies 17,38,39,40 suggest that women in this kind of relationship may lack control over the timing of sexual intercourse and are less likely to adopt contraception, thereby increasing the likelihood of unwanted pregnancy. Another issue worth raising here is the fact that women who suffer violence by an intimate partner may have less decision-making power to interrupt an unintended pregnancy when the contraceptive method fails and is unable to exercise control over their fertility 18 .

Among the study's limitations, we point out that it was carried out using the baseline of a cohort of women whose pregnancy progressed to a birth. Several studies $41,42,43$ have found an association between intimate partner violence and abortion and pointed out that most pregnancies ending in induced abortion are unintended. Our study may thus have underestimated the extent of unintended pregnancy and its association with intimate partner violence. In retrospective reports of pregnancy intention, women may rationalize an unwanted pregnancy as a wanted birth shifting to a more positive response, reclassifying a child from being "unwanted" to "wanted" $44,45,46$. In this study, the description of the pregnancy as intended or not may have been influenced by the interview having been conducted late in pregnancy 47.

The same phenomenon has occurred with the investigation of violence, because although women were asked about the history of intimate partner violence in the period prior to conception, this information was collected retrospectively, which may have resulted in some misclassification. However, any measurement error with regard to partner violence would be expected to be random and would have reduced the strength of the observed association.

Several strengths of this study need to be highlighted. The large sample with an excellent response rate provided a representative com- 
munity sample of poor people in this setting. We used an internationally recognized questionnaire that takes a non-judgmental and more acceptable approach to this sensitive subject. We were also able to adjust for a large number of possible confounding variables and a conceptual framework was used to manage the complex hierarchical inter-relationship between intimate partner violence and unintended pregnancy.

\section{Resumen}

Se investigó la asociación entre el embarazo no deseado y la violencia de género antes del embarazo. Se trata de un estudio transversal con 1.054 mujeres de entre 18 y 49 años, que viven en Recife, nordeste de Brasil, entre julio de 2005 y marzo de 2006. Se utilizó el análisis de regresión logística con una estrategia jerárquica para la inserción de variables en el modelo, de acuerdo con un marco conceptual definido. El embarazo no deseado fue informado por un 60,3\% (636) mujeres. La violencia de género antes del embarazo se asocia con embarazos no deseados $\left(O R_{a j}=1.57\right.$; IC95\%: 1.17-2.11), incluso después de ajustarla por las características demográficas y socioeconómicas de las mujeres, comportamiento de la pareja y la dinámica de la relación. Cuando la asociación fue ajustada para el uso de anticonceptivos y la negativa del compañero para usar anticonceptivos, hubo pérdida de significación estadística. Esto sugiere que el efecto de violencia de género en el embarazo no deseado puede estar influenciado por estas variables. Los hallazgos apuntan a la necesidad de la detección de violencia de género en los servicios de salud reproductiva.

Violencia Contra la Mujer; Maltrato Conyugal; Embarazo no Planeado; Salud Reproductiva
Finally, the study's findings point to the need for further research into reproductive issues and violence against women, an aspect that should be focused in many studies of contraception, unintended pregnancy, and abortion. Furthermore, it shows the importance of reproductive health services addressing the relational aspect of contraception and highlights the need to enhance the quality of health care for women in order to better identify intimate partner violence and provide appropriate assistance.

\section{Contributors}

T. V. B. Araújo participated in the original idea, design, data analysis and interpretation, and drafting the manuscript. A. C. C. Azevêdo participated in the original idea, data analysis and interpretation, and drafting the manuscript. S. Valongueiro participated in the original idea, study design, interpretation of the results, and drafting the manuscript. A. B. Ludermir participated in the original idea, study design, interpretation of the results, and drafting the manuscript.

\section{Acknowledgements}

The authors wish to thank DECIT and CNPq, Brazil (grant numbers 403060/2004-4 and 473545/2004-7), for funding the research. 


\section{References}

1. Gipson JD, Koenig MA, Hindin MJ. The Effects of unintended pregnancy on infant, child, and parental health: a review of the literature. Stud Fam Plann 2008; 39:18-38.

2. Fisher RC, Stanford JB, Jameson P, DeWitt MJ. Exploring the concepts of intended, planned, and wanted pregnancy. J Fam Pract 1999; 48:117-22.

3. Klerman LV. The intendedness of pregnancy: a concept in transition. Matern Child Health J 2000; 4:155-62.

4. Barret G, Smith SC, Wellings K. Conceptualisation, development, and evaluation of a measure of unplanned pregnancy. J Epidemiol Community Health 2004; 58:426-33.

5. Ministério da Saúde; Centro Brasileiro de Análise e Planejamento. Pesquisa nacional de demografia e saúde da criança e da mulher - PNDS 2006: dimensões do processo reprodutivo e da saúde da criança. Brasília: Ministério da Saúde, 2009. (Série G. Estatística e Informação em Saúde).

6. Gazmararian JA, Adams MM, Saltzman LE, Johnson $\mathrm{CH}$, Bruce C, Marks JS, et al. The relationship between pregnancy intendedness and physical violence in mothers of newborns. The PRAMS Working Group. Obstet Gynecol 1995; 85:1031-8.

7. Goodwin MM, Gazmararian JA, Johnson CH, Gilbert BC, Saltzman LE Pregnancy intendedness and physical abuse around the time of pregnancy: findings from the pregnancy risk assessment monitoring system, 1996-1997. PRAMS Working Group. Pregnancy Risk Assessment Monitoring System. Matern Child Health J 2000; 4:85-92.

8. Pallitto CC, O'Campo P. The relationship between intimate partner violence and unintended pregnancy: analysis of a national sample from Colombia. Int Fam Plan Perspect 2004; 30:165-73.

9. Silverman J, Gupta J, Decker M, Kapur N, Raj A. Intimate partner violence and unwanted pregnancy, miscarriage, induced abortion, and stillbirth among a national sample of Bangladeshi women. BJOG 2007; 114:1246-52.

10. Cripe SM, Sanchez SE, Perales MT, Lam N, Garcia P, Williams MA. Association of intimate partner physical and sexual violence with unintended pregnancy among pregnant women in Peru. Int J Gynecol Obstet 2008; 100:104-8.

11. Wanzhen G, Janis P, Sarnia C, Leon I. Intimate partner violence and unplanned pregnancy in the Pacific Islands Families Study. Int J Gynecol Obstet 2008; 100:109-15.

12. Schraiber LB, Oliveira AFPL, França-Junior I, Diniz S, Portella AP, Ludermir AB. Prevalência da violência contra a mulher por parceiro íntimo em regiões do Brasil. Rev Saúde Pública 2007; 41:797-807.

13. Silva EP, Ludermir AB, Araújo TVB, Valongueiro AS. Frequency and pattern of intimate partner violence before, during and after pregnancy. Rev Saúde Pública 2011; 45:1044-53.

14. Gomes APPF. Situação de saúde e violência contra as mulheres no Recife, PE [Dissertação de Mestrado]. Recife: Centro de Pesquisa Aggeu Magalhães, Fundação Oswaldo Cruz; 2008.
15. Pallitto CC. Domestic violence and maternal, infant, and reproductive health: a critical review of the literature. Washington DC: Pan American Health Organization; 2004.

16. Pallitto CC, O'Campo P. Community level effects of gender inequality on intimate partner violence and unintended pregnancy in Colombia: testing the feminist perspective. Soc Sci Med 2005; 60:205-21.

17. Williams CM, Larsen U, McCloskey LA. Intimate partner violence and women's contraceptive use. Violence Against Women 2008; 14:1382-96.

18. Gee RE, Mitra N, Wan F, Chavkin DE, Long JA. Power over parity: intimate partner violence and issues of fertility control. Am J Obstet Gynecol 2009; 201:1481-7.

19. Prefeitura da Cidade do Recife. Plano municipal de saúde 2006-2009. http://www.recife.pe.gov. $\mathrm{br} /$ noticias/arquivos/227.pdf (accessed on 01/ Nov/2012).

20. Schraiber LB, Latorre, MRD, França-Junior I, Segri NJ, D'Oliveira AFPL. Validade do instrumento WHO VAW STUDY para estimar violência de gênero contra a mulher. Rev Saúde Pública 2010; 44:658-66.

21. Ludermir AB, Lewis G, Valongueiro SV, Araújo TVB, Araya R. Violence against women by their intimate partner during pregnancy and postnatal depression: a prospective cohort study. Lancet 2010; 376:903-10.

22. Instituto Brasileiro de Geografia e Estatística. Anuário estatístico do Brasil. Rio de Janeiro: Instituto Brasileiro de Geografia e Estatística; 1992.

23. Victora CG, Huttly SR, Fuchs SC, Olinto MT. The role of conceptual frameworks in epidemiological analysis: a hierarchical approach. Int J Epidemiol 1997; 26:224-7.

24. Prietsch SOM, Gonzalez-Chica DA, Cesar JA, Mendoza-Sassi RA. Gravidez não planejada no extremo Sul do Brasil: prevalência e fatores associados. Cad Saúde Pública 2011; 27:1906-16.

25. Cubbin C, Braveman PA, Marchi KS, Chavez GF. Socioeconomic and racial/ethnic disparities in unintended pregnancy among postpartum women in California. Matern Child Health J 2002; 6:237-46.

26. Green DC, Gazmararian, JA, Mahoney LD, Davis NA. Unintended pregnancy in a commercially insured population. Matern Child Health J 2002; 6:181-7.

27. Le LC, Magnani R, Rice J, Speizer I, Bertrandet W. Reassessing the level of unintended pregnancy and its correlates in Vietnam. Stud Fam Plann 2004; 35:15-26.

28. Finer LB, Henshaw K. Disparities in rates of unintended pregnancy in the United States, 1994 and 2001. Perspec Sex Reprod Health 2006; 38:90-6.

29. Custer M, Waller K, Vernon S, O'Rourke K. Unintended pregnancy rates among a US military population. Paediatr Perinat Epidemiol 2008; 22: 195-200.

30. Font-Ribera L, Perez G, Salvador J, Borrell C. Socioeconomic inequalities in unintended pregnancy and abortion decision. J Urban Health 2008; 85:125-35. 
31. Shaheen AA, Diaaeldin M, Chaaya M, El Roueiheb Z. Unintended pregnancy in Egypt: evidence from the national study on women giving birth in 1999 . East Mediterr Health J 2007; 13:1392-404.

32. Chandra A, Martinez GM, Mosher WD, Abma JC, Jones J. Fertility, family planning, and reproductive health of U.S. women: data from the 2002 National Survey of Family Growth. Hyattsville: National Center for Health Statistics, Centers for Disease Control and Prevention, U.S. Department Of Health And Human Services; 2005. (Vital Health Statistics, Series 23, 25).

33. Menezes GMS, Aquino EML, Silva DO. Induced abortion during youth: social inequalities in the outcome of the first pregnancy. Cad Saúde Pública 2006; 22:1431-46.

34. Ellsberg M, Heise L, Peña R, Agurto S, Winkvist A. Researching domestic violence against women: Methodological and ethical considerations. Stud Fam Plann 2001; 32:1-16.

35. Faúndes A, Hardy E, Osis MJ, Duarte G. O risco para queixas ginecológicas e disfunções sexuais segundo história de violência sexual. Rev Bras Ginecol Obstet 2000, 22:153-7.

36. Fanslow J, Whitehead A, Silva M, Robinson E. Contraceptive use associations with intimate partner violence among a population-based sample of New Zeland women. Aust N Z J Obstet Gynaecol 2007; 48:83-9.

37. Pirotta KCM. Não há guarda-chuva contra o amor: estudo do comportamento reprodutivo e de seu universo simbólico entre jovens universitários da USP [Tese de Doutorado]. São Paulo: Faculdade de Saúde Pública, Universidade de São Paulo; 2002.

38. Heise L. Reproductive freedom and violence against women: Where are the intersections? J Law Med Ethics 1993; 21:206-16.
39. Heise L, Moore K, Toubia N. Sexual coercion and reproductive health: a focus on research. New York: Population Council; 1995.

40. Coker AL. Does physical intimate partner violence affect sexual health? A systematic review. Trauma Violence Abuse 2007; 8: 149-77.

41. Moore ML, Michielutte R, Parsons LH. The prevalence of domestic violence among women seeking abortion. Obstet Gynecol 1998; 91:1002-6.

42. Fisher WA, Singh SS, Shuper PA, Carey M, Otchet F, MacLean-Brine D. Characteristics of women undergoing repeat induced abortion. CMAJ 2005; 172:637-41.

43. Woo J, Fine P, Goetzl L. Abortion disclosure and the association with domestic violence. Obstet Gynecol 2005; 105:1329-34.

44. Bankole A, Westoff C. The consistency and validity of reproductive attitudes: evidence from Marroco. J Biosoc Sci 1998; 30:439-55.

45. Williams L, Abma J. Birth wantedness reports: a look forward and a look back. Biodemography Soc Biol 2000; 47:147-63.

46. Koenig MA, Acharya R, Singh S, Roy TK. Do current measurement approaches underestimate levels of unwanted childbearing? Evidence from rural India. Popul Stud (Camb) 2006; 60:243-56.

47. Poole VL, Flowers JS, Goldenberg RL, Cliver SP, McNeal S. Changes in intendedness during pregnancy in a high-risk multiparous population. Matern Child Health J 2000; 4:179-82.

Submitted on 11/Dec/2011

Final version resubmitted on 01/Apr/2013 Approved on 27/Jul/2013 